\title{
PENGARUH KEMAMPUAN GURU MENGGUNAKAN MEDIA BERBASIS KOMPUTER TERHADAP PERHATIAN PESERTA DIDIK DALAM PEMBELAJARAN PAI DI SMPN 2 PINRANG
}

\author{
Aljinnah \\ SMPN 2 Pinrang \\ Email: hj.aljinnah@gmail.com
}

\begin{abstract}
This article discusses the influence of teacher ability using computer-based media to the attention of learners on learning PAI in SMPN 2 Pinrang Regency. This toward study aims to determine the ability of teachers using computer-based media, the attention of learners on learning PAI in SMPN 2 Pinrang regency, and the effect of teacher ability using computer-based media to the attention of learners on learning PAI in SMPN 2 Pinrang regency. This type of research is quantitative research, as it find the objective, valid, and reliable data using numerical data, preferably observation, questionnaires, documentation. Data obtained through observation, questionnaires, and documentation. The results of this study indicate that the ability of teachers using computer-based learning media significantly influence the attention of learners on learning PAI SMPN 2 Pinrang District. Known from the results of hypothesis testing was proposed alternative hypothesis can be accepted. Based on the calculation, $r$ calculated $=1,000>r$ table $=0,169$ at $5 \%$ significant level so it is concluded that ho is rejected and ha is accepted. Means there is a significant positive influence between variables $x$ and $y$ variables. $T$ test results show $t$ arithmetic greater than $t$ table, 6.029>1.985, meaning Ho rejected or Ha accepted. the calculation results obtained by determination coefficient of 0.27,7 means the correlation value of 27.7 percent of independent variables can explain the deviation and dependent variables.Some of the implications in this study as a form of learning process development is the school is expected to facilitate the process of computer-based learning. Availability of infrastructure facilities will maximize the motivation, interest and attention of learners so that achievement and learning outcomes can be maximized.
\end{abstract}

Keyword: Ability, Computer-based Media, Attention 


\section{ABSTRAK}

Tesis ini membahas tentang, Pengaruh kemampuan guru menggunakan media berbasis komputer terhadap perhatian peserta didik pada pembelajaran PAI di SMPN 2 Kabupaten Pinrang. Penelitian ini bertujuan untukmengetahui kemampuan guru menggunakan media berbasis komputer, perhatian peserta didik pada pembelajaran PAI di SMPN 2 Kabupaten Pinrang, dan pengaruh kemampuan guru menggunakan media berbasis komputer terhadap perhatian peserta didik pada pembelajaran PAI di SMPN 2 Kabupaten Pinrang.Jenis penelitian ini termasuk penelitian kuantitatif, karena berusaha mendapatkan data yang obyektif, valid, dan reliable dengan menggunakan data yang berbentuk angka, lebih mengutamakan observasi, kuesioner, dokumentasi. Data diperoleh melalui observasi, kuesioner, dan dokumentasi. Hasil penelitian ini menunjukkan bahwa kemampuan guru menggunakan media pembelajaran berbasis komputer berpengaruh secara signifikan perhatian peserta didik pada pembelajaran PAI SMPN 2 Kabupaten Pinrang.Diketahui dari hasil pengujian hipotesis ternyata hipotesis alternatif yang diajukan dapat diterima.Berdasarkan hasil perhitungan, diperoleh $r_{\text {hitung }}=1,000$ $\geq r_{\text {tabel }}=0,169$ pada taraf signifikan $5 \%$ sehingga disimpulkan bahwa $\mathrm{h}_{\mathrm{o}}$ ditolak dan $h_{a}$ diterima. Berarti terdapat pengaruh positif yang signifikan antara variabel $x$ dan variabel y.Hasil Uji T menunjukkan $t_{\text {hitung }}$ lebih besar dari $t_{\text {tabel }} 6,029 \geq 1.985$, artinya Ho ditolak atau Ha diterima. Dan hasil perhitungan diperoleh koefisien determinasi sebesar 0,27,7 artinya nilai korelasi sebesar 27,7 persen variabel independen dapat menjelaskan deviasi dan variabel dependen.Beberapa yang implikasi dalam penelitian ini sebagai bentuk pengembangan proses pembelajaran yaitu pihak sekolah diharapkan memfasilitasi proses pembelajaran yang berbasis komputer. Ketersedian sarana prasarana akan memaksimalkan motivasi, minat dan perhatian peserta didik sehingga prestasi dan hasil belajar bisa maksimal.

Kata Kunci: Kemampuan, Media Berbasis Komputer,Perhatian.

\section{PENDAHULUAN}

\section{Latar Belakang}

Pendidikan Agama Islam sangat memperhatikan segala aspek kehidupan umat manusia termasuk masalah pendidikan. Al-Qur'an menegaskan petunjuk dan prinsip-prinsip yang berkaitan dengan usaha pendidikan. Oleh sebab itu, Islam bukan hanya menganjurkan umatnya untuk rajin belajar dan menggali berbagai ilmu, tetapi juga menghargai dan meninggikan derajat mereka yang sudah memiliki ilmu, sebagaimana firman Allah dalam Q.S. al-Mujadalah/58: 11, yang berbunyi: 


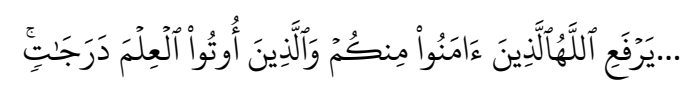

Terjemahnya:

... Niscaya Allah akan meninggikan orang-orang yang beriman di antaramu dan orang-orang yang diberi ilmu pengetahuan beberapa derajat. ${ }^{1}$

Berdasarkan ayat tersebut di atas, menunjukkan bahwa orang yang beriman dan berilmu pengetahuan merupakan proses pembentukan kepribadian untuk menuju kebahagiaan hidup, yang harus dimiliki dan tertanam dalam diri setiap umat Islam.

Kehadiran media pembelajaran sebagaisalah satu komponen dalam proses pembelajaran amat diperlukan, mengingat bahwa kedudukan media ini bukan hanya sekedar alat bantumengajar, tetapi merupakan bagian integral dalam pembelajaranselain dapat menggantikan sebagian tugas guru sebagai penyaji materi (penyalur pesan) media juga memiliki potensi-potensi yang unik, yangdapat membantu peserta didik dalam belajar. ${ }^{2}$

Media menjadi bagian yang tidak terpisahkan dalam proses pembelajaran. Ia tidak hanya sebagai alat bantu, akan tetapi jugasebagai alat penyalur pesan-pesan pendidikan. Guru sebagai sumberbelajar utama bagi peserta didik, ia tidak boleh berpandangan sebagai satu-satunya sumber, karena sumber belajar lainnya seperti: buku teks ajar,alam lingkungan, media masa cetak, dan media masa elektronik dapatberperan dalam proses pembelajaran. ${ }^{3}$

Media komputer akan lebih memudahkan peserta didik menerimadan mengingatkan materi yang telah disampaikan. Manfaatlain, akan memudahkan guru dalam menyimpan materi, karena dapat ditumbuhkan secara langsung kepada peserta didik. Suatu bukti kongkrit berupa sarana dan gambar bergerak karena media ini berhubungan langsung dengan indra penglihatan dan pendengaran.

Berdasarkan realitas diatas cukup relevan bagi peneliti untuk menjadikan sebagai wacana penelitian dengan judul "PengaruhKemampuan Menggunakan Media berbasis Komputer terhadap Perhatian Peserta didik dalam Pembelajaran Pendidikan Agama Islampada kelas VIII SMPN 2 Pinrang”.

\section{Rumusan Masalah}

Berdasarkan latar belakang dan identifikasi masalah diatas, maka penelitian diarahkan pada masalah sebagaimana yang dirumuskan yang meliputi:

\footnotetext{
${ }^{1}$ Departemen Agama, al-Qur'an dan Terjemahnya (Semarang: Toha Putra, 2003), h. 910.

${ }^{2}$ Karti Soenarto, dkk, Teknologi Pembelajaran (Surabaya: SIC, 2003), h. 98.

${ }^{3}$ Thoifuri, Menjadi Guru Inisiator (Semarang: RaSAIL Media Group, 2007), h. 167
} 
1. Bagaimana kemampuan gurumenggunakan media berbasis komputer dalam pembelajaran PAIpadapeserta didik Kelas VIII SMPN 2 Pinrang?

2. Bagaimana perhatian peserta didik dalam pembelajaran PAI Kelas VIII pada SMPN 2 Pinrang?

3. Apakah ada pengaruhkemampuan menggunakan media berbasis komputer terhadap perhatian peserta didik dalam pembelajaran PAI Kelas VIII pada SMPN 2 Pinrang?

\section{Kemampuan Guru}

Kemampuan guru merupakan kompetensi seorang guru dalam melaksanakan profesi keguruannya.Pekerjaan yang profesional memerlukan beberapa bidang ilmu yang sengaja dipelajari kemudian diaplikasikan bagi kepentingan umum.Dengan demikian tugas guru sebagai tugas profesi yang menuntut kemampuan dan keahlian khusus dalam bidang keguruan sehingga mampu melakukan tugas dan fungsinya sebagai guru dengan kemampuan optimal. ${ }^{4}$

Berdasarkan beberapa pengertian tersebut baik secara bahasa maupun secara istilah, guru dapat dipahami sebagai orang-orang yang bertanggung jawab terhadap perkembangan anak didik.Dimana tugas seorang guru adalah mendidik yakni mengupayakan perkembangan seluruh potensi anak didik, baik potensi kognitif, potensi afektif maupun potensi psikomotorik.

Kemampuan guru menurut Marsudi adalah:

a. Guru merancang dan mengelola kegiatan pembelajaran yang mendorong peserta didik untuk berperan aktif dalam pembelajaran.

b. Guru menggunakan alat bantu dan sumber belajar yang beragam guru memberikan peluang kepada peserta didik untuk mengembangkan keterampilan.

c. Guru memberikan kesempatan kepada peserta didik untuk mengungkapkan gagasannya sendiri secara lisan dan tulisan.

d. Guru menyesuaikan bahan dan kegiatan belajar dengan kemampuan peserta didik sendiri.

e. Guru mengaitkan kegiatan pembelajaran dengan pengelamannya sendiri.

f. Guru menilai kegiatan pembelajaran dan kemajuan peserta didik secara terus menerus. ${ }^{5}$

\footnotetext{
${ }^{4}$ Moh. Uzer Usman, Menjadi Guru Profesional (Bandung: Remaja Rosdakarya, 2011), $\quad$ h. 1415.

${ }^{5}$ Marsudi Wahyu Kisworo, Revolusi Mengajar: Pembelajaran Aktif, Kreatif, Efektif, Menyenangkan (Pakem) (Jakrta: Asik Generation, 2016), h. 93
} 
Berdasarkan uraian tersebut dapat peneliti ambil kesimpulan bahwa kemampuan guru adalah yang berkaitan dengan tugas dan tanggung jawab sebagai pendidik. untuk melakukan tugasnya dalam proses pembelajaran.

\section{Penggunaan Media Komputer}

Gerlach \& Ely (1971) yang dikutip Azhar Arsyad menyatakan bahwa media apabiladipahami secara garis besar adalah manusia, materi atau kejadian yang membangun kondisi yang membuat peserta didik mampu memperoleh pengetahuan. ${ }^{6}$ Dalam pengertian ini, guru, buku teks, dan lingkungan sekolah merupakan media. Secara lebih khusus, pengertian media dalam proses belajar mengajar cenderung diartikan sebagai alat-alat grafis, photografis, atau elektronisuntuk menangkap, memproses dan menyusun kembali informasi visual atau verbal.

Sejalan dengan pengertian diatas, media merupakan wahana penyalur pesan atau informasi belajar, yakni segalasesuatu yang dapat digunakan untuk merangsang pikiran, perasaan, perhatian dan kemauan peserta didik sehingga dapat mendorong terjadinya proses belajar pada diri peserta didik. ${ }^{7}$

Dari beberapa pendapat diatas dapat disimpulkan bahwa media adalah segala sesuatu yang dapat digunakan untuk menyalurkan pesan dari pengirim ke penerima sehingga dapat merangsang pikiran, perasaan, perhatian, dan minat serta perhatian peserta didik sedemikian rupa sehingga proses belajar terjadi.

\section{Perhatian Peserta Didik}

Perhatian memiliki beberapa definisi.Menurut Khairani bahwa perhatian adalah keaktifan peningkatan kesadaran dalampemusatannya kepada barang sesuatu baik di dalam maupun di luar diri kita. ${ }^{8}$ Sedangkan perhatian menurut Sumadi Suryabrata merupakanpemusatan tenaga psikis yang tertuju kepada suatu objek.Jadi, perhatian adalahpemusatan tenaga psikis yang tertuju kepada suatu objek baik di dalam maupundi luar kita. ${ }^{9}$ Hal tersebut senada dengan yang diungkapkan Baharudin perhatian merupakan pemusatan atau konsentrasi dari seluruh aktifitasindividu yang ditunjukan kepada sekumpulan objek. ${ }^{10}$ Hendra Surya menyatakan bahwa perhatian merupakan prosespemusatan pengerahan

\footnotetext{
${ }^{6}$ Azhar Arsyad, Media Pembelajaran..., h. 2.

${ }^{7}$ Muhaimin, Arah Baru Pengembangan Pendidikan Agama Islam (Bandung: Nuansa, 2003), h. 132-133.

${ }^{8}$ Makmun Khairani. Psikologi Belajar (Yogyakarta: Aswaja Pressindo. 2013), h. 154.

${ }^{9}$ Sumadi Suryabrata. Psikologi Pendidikan(Jakarta: Raja GrafindoPersada. 2008), h. 14.

${ }^{10}$ Baharudin.Psikologi Pendidikan Refleksi Teoritis terhadap Fenomena.(Yogyakarta: Ar- Ruzz Media. 2007), h. 178.
} 
aktivitas tenaga psikis (pikiran) dan fisik terutama indraserta gerakan tubuh pada fokus tertentu. ${ }^{11}$

Berdasarkan uraian di atas, dapat ditarik kesimpulan bahwa perhatian merupakan suatu aktivitas untuk memusatkan tenaga psikis atau pikiran dan fisik terhadap suatu objek. Perhatian peserta didik dalam proses pembelajaran yaitu aktivitas peserta didik untuk memusatkan konsentrasi dalam mendengarkan dan mencermati apa yang disampaikan guru terhadap pembelajaran yang sedang berlangsung.

Syaiful Bahri Djamarah menyebutkan bahwa yang menjadi indikator perhatiandalam aktivitas pembelajaran meliputi:

a) Mendengarkan. Setiap siswa yang belajar di sekolah pasti mendengarkan.Dalam mendengarkan apa yang diceramahkan guru, tidak dibenarkan adanya hal-hal yang mengganggu jalannya ceramah. Karena hal itu dapat mengganggu perhatian siswa. Siswa yang memperhatikan pasti berkonsentrasi mendengarkan guru yang sedang menjelaskan. Dan tidak ada kegiatan lain yang mengganggu siswa dalam mendengarkan. Dan bagaimanapun juga gangguan itu pasti ada dan tidak dapat dihilangkan, tetapi dapat dikurangi.

b) Memandang. Memandang adalah mengarahkan penglihatan ke suatu objek. Di dalam kelas, siswa memandang papan tulis yang berisikan tulisan yang baru saja guru tulis. Siswa yang tidak memandang apa yang guru jelaskan dalam papan tulis, maka siswa akan sulit memahami apa yang dimaksud oleh guru. Memandang yang baik yaitu mempertahankan kontak mata terhadap guru.

c) Menulis atau mencatat. Dalam pendidikan tradisional mencatat merupakan aktivitas yang sering dilakukan. Walaupun padawaktu tertentu siswa harus mendengarkan isi ceramah, namun siswa tidak bisa mengabaikan masalah mencatat hal-hal yang dianggap penting. Mencatat merupakan kegiatan siswa yang mempermudah siswa itu sendiri. Untuk memperoleh hasil yang baik, maka mencatat hendaknya dengan kesadaran diri. Siswa dapat mencatat apa yang guru sampaikan.

d) Membaca. Membaca adalah aktivitas belajar yang paling banyak dilakukan selama belajar di sekolah bahkan di perguruan tinggi. Jika belajar adalah untuk mendapatkan ilmu pengetahuan, maka membaca adalah jalan menuju ke pintu ilmu pengetahuan. Tanpamembaca siswa tidak dapat dikatakan belajar. Karenabelajar selalu diawali dengan membaca. Membaca dalam hal belajar

\footnotetext{
${ }^{11}$ Hendra Surya, Menjadi Manusia Pembelajan(Jakarta: Elex Media Komputindo. 2009), h. 3.
} 
tidak hanya sekedar membaca sebuah tulisan, akan tetapi juga mengerti maksud dari apa yang siswa baca.

e) Membuat ringkasan dan menggaris bawahi. Ringkasan dapat membantu dalam hal mengingat atau mencari kembali materi dalam buku. Sedangkan membaca dalam hal-hal penting perlu digaris bawahi. Bagi peserta didikmembuat ringkasan ialah menuliskan hal-hal penting yang dalam pembelajaran.

f) Mengamati tabel-tabel, diagram-diagram, dan bagan-bagan. Di dalam buku sering dijumpai tabel-tabel, diagram-diagram, ataupun bagan-bagan. Materi non verbal inisangat berguna bagi peserta didikdalam mempelajari materi yang relevan. Demikian pula gambar-gambar, peta-peta dan lain-lain dapat menjadi bahan ilustratif yang membantu pemahaman siswa tentang sesuatu hal. Untuk memperjelas suatu materi tertentu, biasanya guru menggunakan bantuan tabel, diagram atau bagan-bagan dalam menyampaikan materi tersebut.

g) Mengingat. Ingatan adalah kemampuan jiwa untuk memasukkan, menyimpan, dan menimbulkan kembali hal-hal yang telah lampau. Perbuatan mengingat jelas sekali terlihat ketika peserta didiksedang menghafal bahan pelajaran, berupa dalil, kaidah, pengertian, rumus dan sebagainya. Bagi seorang peserta didik, untuk mata pelajaran tertentu membutuhkan ingatan yang baik. Ingatan tidak hanya satu hari langsung hilang, akan tetapi ingatan yang baik yaitu dapat bertahan hingga lama.

h) Berfikir. Dengan berpikir peserta didikmemperoleh penemuan baru, setidaknya siswa menjadi tahu tentang hubungan antara sesuatu. Berpikir bukanlah sembarang berpikir, tetapi ada taraftertentu. Peserta didikyang dapat mengerjakan soal akan tetapi hanya menyalin jawaban teman, maka siswa tersebut belum dapat dikatakan berfikir.

i) Latihan atau praktik. Belajar sambil berbuat termasuk dalam latihan. Latihan termasuk cara yang baik untuk memperkuat ingatan. Dengan banyak latihan kesan-kesan yang diterima lebih fungsional. Dengan demikian, latihan dapat mendukung belajar. ${ }^{12}$

Aktivitas pembelajaran merupakan aktivitas peserta didik yang ditunjukan untuk menaruh perhatian ketika kegiatan belajar mengajar.Aktivitas peserta didik dalam hal perhatian adalah mendengarkan, memandang, menulis, membaca, dan berpikir.

\footnotetext{
${ }^{12}$ Syaiful Bahri Djamarah. Psikologi Belajar (Jakarta: Rineka Cipta. 2011), h. 38
} 


\section{Kerangka Teori}

Kerangka teori yang dimaksudkan dalam penelitian ini adalah alur pikir yang dijadikan pijakan atau acuan dalam memahami masalah yang diteliti. Kerangka ini merupakan sintesa tentang hubungan antar variabel yang disusun dari berbagai teori yang telah dideskripsikan.Berdasarkan teori-teori yang telah dideskripsikan tersebut, selanjutnya dianalisis secara sistematis sehingga menghasilkan sintesa antar variabel yang diteliti.

Teori yang digunakan dalam penelitian ini di antaranya, yang dikemukakan oleh Marsudi dan Wina Sanjaya tentang kemampuan guru. ${ }^{13}$ Serta menurut Syaiful Bahri Djamarah tentang perhatian peserta didik. ${ }^{14}$ Selengkapnya dapat dilihat pada bagan atau skema kerangkan teori di bawah ini.

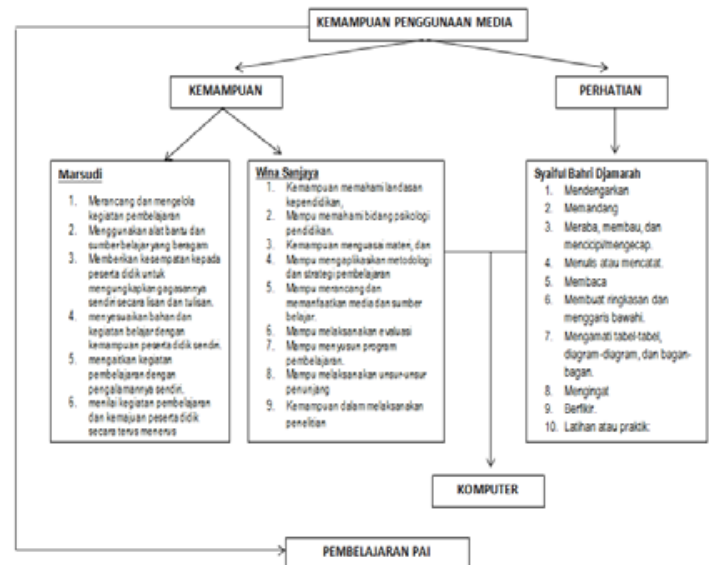

\section{Jenis dan Pendekatan Penelitian}

Penelitian ini merupakan jenis penelitian lapangan (field research)yaitupenelitian yang dilakukan dengan mengumpulkan data dan informasi yang diperoleh langsung dari responden dan mengamati secara langsung.Bila dilihat dari jenis datanya, penelitian ini termasuk penelitian kuantitatif, karena berusaha mendapatkan data yang obyektif, valid, dan reliable dengan menggunakan data yang berbentuk angka, atau data yang diangkakan. ${ }^{15}$

Jenis penelitian ini menggunakan metode penelitian asosiatif.Penelitian asosiatif merupakan penelitian yang bertujuan untuk mengetahui hubungan antara dua variabel atau lebih.Penelitian asosiatif mempunyai tingkatan yang tertinggi bila

\footnotetext{
${ }^{13}$ Marsudi Wahyu Kisworo, Revolusi Mengajar: Pembelajaran Aktif, Kreatif, Efektif, Menyenangkan (Pakem)..., h. 93 dan Wina Sanjaya, Pembelajaran Dalam Implementasi Kurikulum Berbasis Kompetensi..., h. 19

${ }^{14}$ Syaiful Bahri Djamarah. Psikologi Belajar..., h. 38

${ }^{15}$ Sugiyono, Statistik untuk Penelitian (Bandung; Alpabeta: 2004), h. 7.
} 
dibandingkan dengan penelitian deskriptif dan komparatif.Dengan penelitian asosiatif ini maka akan dapat dibangun suatu teori yang dapat berfungsi untuk menjelaskan, meramalkan dan mengontrol suatu gejala. ${ }^{16}$

Pendekatan yang digunakan dalam penelitian ini adalah pendekatan multidisipliner antara lain pendekatan paedagogis, psikologis danmanajemen.

\section{Waktu dan Lokasi Penelitian}

Penelitian ini dilaksanakan pada bulan Mei-Juni 2017. Setelah dilakukan seminar proposal dan disetujui oleh tim penguji dan tim pembimbing, dan telah mendapatkan ijin penelitian dari pemerintah daerah setempat.

Lokasi yang menjadi tempat penelitian ini adalah di SMP Negeri 2 Pinrang yang terletak di Benteng, Macinnae, Kecamatan Paleteang, Kabupaten Pinrang, Sulawesi Selatan.Gambaran umum SMP Negeri 2 Pinrangadalah lembaga pendidikan formal setingkat Sekolah Lanjut Tingkat Pertama (SLTP).

\section{Populasi dan Sampel}

Populasi merupakan keseluruhan individu yang merupakan sumber informasi data. Informasi mengenai sesuatu yang ada hubungannya dengan penelitian tentang data yang diperlukan.

Adapun yang menjadi populasi dalam penelitian ini adalah peserta didik kelas VIII SMP Negeri 2 Pinrangyang terdiri dari 12 rombongan belajar dengan jumlah peserta didik sebanyak 400 orang. Populasi tersebut mempunyai karakteristik yang beragam baik kemampuan akademik, maupun latar belakang sosialnya. Untuk lebih lengkap dapat dilihat pada tabel berikut ini:

\footnotetext{
${ }^{16}$ Sugiyono, Statistik untuk Penelitian..., h. 11.
} 
Tabel 3.1

Keadaan Populasi SMPN 2 Pinrang

\begin{tabular}{|c|c|c|c|}
\hline Kelas VIII & Perempuan & Laki-laki & JUMLAH \\
\hline 1 & 24 & 16 & 40 \\
\hline 2 & 19 & 14 & 33 \\
\hline 3 & 17 & 15 & 32 \\
\hline 4 & 16 & 16 & 32 \\
\hline 5 & 18 & 15 & 33 \\
\hline 6 & 19 & 14 & 33 \\
\hline 7 & 18 & 13 & 31 \\
\hline 8 & 16 & 18 & 34 \\
\hline 9 & 20 & 14 & 34 \\
\hline 10 & 17 & 16 & 33 \\
\hline 11 & 16 & 16 & 32 \\
\hline 12 & 15 & 18 & 33 \\
\hline & 215 & 185 & 400 \\
\hline
\end{tabular}

Dokumentasi: Kantor Tata Usaha SMPN 2 Pinrang

Sampel diartikan sebagai bagian dari populasi yang menjadi sumber data sebenarnya dalam suatu penelitian. Dengan kata lain, sampel adalah sebagian dari populasi untuk mewakili seluruh populasi, atau sampel adalah sebagian yang diambil dari populasi dengan menggunakan cara-cara tertentu. ${ }^{17}$ Oleh karena sampel bagian dari populasi, maka sampel yang diambil harus mencerminkan keadaan umum dari populasi.

Sampel merupakan bagian dari populasi yang representative sehingga hasil penelitian sampel dapat digeneralisir pada seluruh populasi. ${ }^{18}$ Jadi jumlah sampel dalam penelitian ini adalah 97 responden. Peneliti mengambil sampel 3 kelas yaitu, dari kelas VIII. ${ }^{2}$ sebanyak 33 responden, kelas VIII. ${ }^{7}$ sebanyak 31 responden dan kelas VIII. ${ }^{12}$ sebanyak 33 responden dengan menggunakan teknik penentuan sampel purposive sampling. Tehnik purposive sampling yaitu penentuan sampel dengan pertimbangan tertentu.Sampel yang terpilih adalah sampel yang mewakili kelas atas, sedang dan bawah.

\footnotetext{
${ }^{17}$ Hadari Nawawi, Metode Penelitian Bidang Sosial (cet.VII; Yogyakarta: Gajah Mada University Press, 1995), h. 144.

${ }^{18}$ Suharsimi Arikunto. Prosedur Penelitian; Suatu Pengantar Praktik..., h. 109.
} 


\section{Teknik Pengumpulan data}

Pengumpulan data adalah pekerjaan peneliti untuk memperoleh data atau informasi yang dibutuhkan dengan prosedur yang telah ditentukan, atau berdasarkan kaidah-kaidah penelitian yang telah dijadikan acuan oleh para pakar peneliti.

Observasi salah satu teknik yang peneliti gunakan dengan mengamati secara langsung.

Pengamatan tentang masalah yang diperlukan untuk dicatat. Dalam hal ini, peneliti mengamati langsung proses pembelajaran PAI di SMP Negeri 2 Pinrang.

Angket (kuesioner), adalah sejumlah pertanyaan tertulis yang dipergunakan untuk memperoleh informasi dari responden.

Dokumentasi adalah metode yang menggunakan bahan klasik untuk meneliti perkembangan yang khusus yaitu untuk menjawab pertanyaan atau persoalanpersoalan tentang apa, mengapa, kenapa, dan bagaimana.

Metode dokumentasi ini peneliti gunakan untuk memperoleh data mengenai proses pembelajaran yang digunakan. Peneliti mengumpulkan data tertulis tentang SMP Negeri 2 Pinrang dan data-data tertulis serta data-data penting lainnya yang berkaitan dengan penelitian ini.

\section{Instrumen Penelitian}

Instrumen yang digunakan dalam penelitian tesis ini berupa:

a. Pedoman observasi yang peneliti gunakan saat pengamatan pada kegiatan yang dilakukan oleh pendidik disaat melakukan tugasnya di SMP Negeri 2 Pinrang, dan perhatian peserta didik pada saat pembelajaran PAI.

b. Lembaran kuesioner (angket) orang untuk mengukur variabel kemampuan menggunakan media berbasis komputer dan perhatian peserta didik dalam pembelajaran PAI.

\section{Teknik Pengolahan dan Analisis Data}

Proses penyusunan, pengaturan, dan pengolahan data agar dapat digunakan untuk membenarkan atau menyalahkan hipotesis. Data yang telah dikumpulkan diolah kemudian dianalisis.Dengan pengolahan data dimaksudkan untuk mengubah data kasar menjadi data yang lebih halus dan lebih bermakna, sedangkan analisis dimaksudkan untuk mengkaji data dalam hubungannya dengan keperluan pengujian hipotesis penelitian. ${ }^{19}$

\footnotetext{
${ }^{19}$ Nana Sudjana, Tuntunan Penyusunan Karya Ilmiah (Cet. IX; Bandung: Sinar Baru Algesindo, 2005), h. 76.
} 
Data yang terkumpul kemudian dianalisis dengan menggunakan analisis deskriptif dan analisis inferensial. Analisis deskriptif digunakan untuk memperoleh gambaran tentang pengaruh kemampuan menggunakan media berbasis komputer dan perhatian peserta didik pada pembelajaran PAI. Sedangkan analisis inferensial digunakan untuk menguji hipotesis pengaruh kemampuan menggunakan media berbasis komputer terhadap perhatian peserta didik pada pembelajaran PAI. ${ }^{20}$

Untuk keperluan tersebut digunakan rumus persamaan analisis regresisebagai berikut:

$$
\mathbf{Y}=\mathbf{a}+\mathbf{b X}
$$

Keterangan:

$\mathrm{X}=$ Kemampuan menggunakan media berbasis Komputer

$\mathbf{Y}=$ Perhatian peserta didik pada pembelajaran PAI

$\mathrm{A}=$ Konstanta

$\mathrm{B}=$ Koefisien pengaruh kemampuan menggunakan media berbasis komputer terhadap perhatian peserta didik pada pembelajaran PAI

Proses perhitungan rumus-rumus tersebut di atas untuk hasil regresi, korelasi, validitas dan reliabilitas dilakukan dengan bantuan perangkat lunak program SPSS for Windows.

Secara teknis penulisan tesis ini mengacu kepada pedoman penulisan karya ilmiah tahun 2015 yang diterbitkan oleh Tim Penyusun Program Pascasarjana STAIN Parepare. ${ }^{21}$ Jadi prosedur penulisan tesis ini menggunakan pedoman yang telah ditentukan oleh PPs Akademik STAIN Parepare.

\section{PEMBAHASAN}

Kemampuan Guru Menggunakan Media Berbasis Komputer Dalam Pembelajaran PAI Pada Peserta Didik di SMPN 2 Pinrang (Variabel X).

Penggunaan media berbasis komputer dalam proses pembelajaran mempunyai arti yang cukup penting. Karena dalam kegiatan tersebut ketidakjelasan bahan yang disampaikan dapat dibantu dengan menggunakan media pembelajaran sebagai media perantara. Kerumitan bahan yang disampaikan kepada peserta didik dapat disederhanakan dengan bantuan penggunaan media pembelajaran dalam hal ini media pembelajaran berbasis komputer. Penggunaan media pembelajaran berbasis komputer dapat mewakili apa yang kurang mampu guru ucapkan melalui kata-kata

\footnotetext{
${ }^{20}$ Noeng Muhadjir, Metodologi Penelitian Kualitatif (Edisi I; Cet. III; Yogyakarta: Rake Sarasin, 1999), h.49.

${ }^{21}$ Tim Penyusun: Pedoman Penulisan Karya Ilmiah, (Parepare: PPS STAIN Parepare, 2015).
} 
atau kalimat tertentu. Bahkan keabstrakan bahan dapat dikonkritkan dengan kehadiran media visual pada pembelajaran. Dengan demikian peserta didik lebih mudah mencerna bahan, dari pada tidak menggunakan media pembelajaran.

Berdasarkan angket yangdibagikan kepada peserta didikpada penelitian ini, menunjukkan adanya sikap yang beragam tentang kemampuan guru dalam penggunaan media pembelajaran berbasis komputer dalam pembelajaran PAI di SMPN 2 Kabupaten Pinrang. Teknik analisis statistik deskriptif dimaksudkan untuk mengetahui gambaran umum data, cara penyajian data, dan cara meringkas data hasil perhitungan sesuai dengan tujuan penelitian dan untuk mengetahui gambaran umum variabel. Penyajian data dimaksudkan untuk mendeskripsikan penggunaan tabel distribusi frekuensi.

Skor total variabel kemampuan menggunakan media pembelajaran berbasis komputer dalam pembelajaran PAI di SMPN 2 Kabupaten Pinrang yang diperoleh dari hasil penelitian adalah 7444, skor teoritik tertinggi variabel ini setiap responden adalah $24 \times 4=96$, karena jumlah responden 97 orang, maka skor kriterium adalah 96 x $97=9312$. Sehingga, kemampuan menggunakan media pembelajaran berbasis komputer dalam pembelajaran PAI adalah $7444: 9312=$ 0,799 atau 79,9 persen dari kriterium yang ditetapkan. Jadi dapat disimpullkan bahwa kemampuan menggunakan media pembelajaran berbasis komputer dalam pembelajaran PAI termasuk kategori sedang.

\section{Perhatian Peserta Didik Pada Pembelajaran PAI Di SMPN 2 Kabupaten Pinrang (Variabel Y)}

Berdasarkan data hasil angket variabel perhatian peserta didik pada pembelajaran PAI di SMPN 2 Kabupaten Pinrang (variabel Y). jumlah item angket sebelum diuji validitas dan uji realibilitas sebanyak 21 item pertanyaan, dan setelah diuji validitas dan uji realibilitas item angket menjadi 19 item pertanyaaan.

Skor total variabel perhatian peserta didik pada pembelajaran PAIdi SMPN 2 Kabupaten Pinrang (variabel Y) yang diperoleh dari hasil penelitian adalah 6004, skor teoritik tertinggi variabel ini setiap responden adalah $19 \times 4=76$, karena jumlah responden 97 orang, maka skor kriterium adalah 76 x $97=7372$. Sehingga, perhatian peserta didik pada pembelajaran PAIdi SMPN 2 Kabupaten Pinrang (variabel Y)adalah 6004 : $7373=0,815$ atau 81,5 persen dari kriterium yang ditetapkan. Jadi dapat disimpullkan bahwa perhatian peserta didik pada pembelajaran PAIdi SMPN 2 Kabupaten Pinrang (variabel Y) termasuk kategori tinggi.Hal tersebut sesuai dengan hasil pengamatan di lapangan bahwa perhatian peserta didik pada pembelajaran PAI di SMPN 2 Kabupaten Pinrang telah berjalan secara maksimal Karena kemampuan guru menggunakan media. 


\section{Pengaruh Kemampuan Guru Menggunakan Media Pembelajaran Berbasis Komputer Terhadap Perhatian Peserta Didik di SMPN 2 Kabupaten Pinrang.}

Untuk mengetahui pengaruh kemampuan menggunakan media pembelajaran berbasis komputer dengan perhatian peserta didik dI SMPN 2 Kabupaten Pinrang, maka perlu dilakukan pengujian hipotesis. Pengujian hipotesis berisi tentang kebenaran hipotesis berdasarkan data yang diperoleh dari sampel penelitian. Tehnik statistik yang digunakan untuk mengetahui pengaruh kemampuan guru menggunakan media berbasis komputer (variabel $\mathrm{x}$ ) terhadap perhatian peserta didik (variabel y) di SMPN 2 Kabupaten Pinrang adalah dengan mengunakan rumus person produk moment.

Penelitian ini menggunakan analisis korelasi dan regresi linier.Analisis korelasi bertujuan memprediksi besar hubungan variabel tergantung (dependen) dengan menggunakan variabel bebas (independen) yang sudah diketahui persamaannya.Sedangkan analisis regresi bertujuan untuk mengetahui pengaruh yang ditimbulkan pada variabel tergantung (dependen) dengan menggunakan variabel bebas (independen) yang juga diketahui persamaannya.

Hasil perhitungan analisis korelasi uji $\mathrm{F}$, diperoleh nilai $\mathrm{F}$ hitung sebesar 36,351 dengan signifikansi 0,000 jauh lebih kecil dari 0,5, nilai ini dibandingkan dengan nilai $\mathrm{F}$ tabel $(0,05 ; 2 ; 95)=3,94$ menunjukkan $\mathrm{F}$ hitung lebih besar dari $\mathrm{F}$ tabel berarti Ho ditolak dan Ha diterima, artinya kemampuan menggunakan media pembelajaran berbasis komputer terhadap perhatian peserta didik SMPN 2 Kabupaten Pinrang adalah identik. Uji F \{Anova\} mempertegas bahwa karena nilai probalitas kurang dari 0,5 maka model regresi yang diperoleh dapat diberlakukan secara umum di lokasi penelitian serta mewakili kondisi populasi yang sebenarnya.Dari hasil pengujian hipotesis ternyata hipotesis alternatif yang diajukan dapat diterima.

\section{SIMPULAN}

Berdasarkan uraian pada hasil penelitian dan pembahasan dapat disimpulkan hasil penelitian ini sebagai berikut:

1. Kemampuan menggunakan media pembelajaran berbasis komputer di SMPN 2 Kabupaten Pinrang, dapat diketahui dari angket yang telah disebar ke-97 responden, yaitu kemampuan guru menggunakan media berbasis komputer dalam pembelajaran PAI (variabel X) adalah $7444: 9312=0,799$ atau 79,9 persen dari kriterium yang ditetapkan. Jadi dapat disimpullkan bahwa kemampuan guru menggunakan media pembelajaran berbasis komputer dalam pembelajaran PAI termasuk kategori sedang. 
2. Perhatian peserta didik yang diketahui dengan hasil hitung angket yang telah disebar ke 97 responden, dapat diketahui bahwaperhatian peserta didik pada pembelajaran PAIdi SMPN 2 Kabupaten Pinrang (variabel Y)adalah 6004 : $7373=0,815$ atau 81,5 persen dari kriterium yang ditetapkan. Jadi dapat disimpullkan bahwa perhatian peserta didik pada pembelajaran PAIdi SMPN 2 Kabupaten Pinrang (variabel Y) termasuk kategori tinggi.

3. Kemampuan guru menggunakan media pembelajaran berbasis komputer berpengaruh secara signifikan perhatian peserta didik pada pembelajaran PAI SMPN 2 Kabupaten Pinrang. Diketahui dari hasil pengujian hipotesis ternyata hipotesis alternatif yang diajukan dapat diterima. Berdasarkan hasil perhitungan, diperoleh $r_{\text {hitung }}=\quad 0,461 \geq r_{\text {tabel }}=0,169$ pada taraf signifikan 5 $\%$ sehingga disimpulkan bahwa $\mathrm{h}_{\mathrm{o}}$ ditolak dan $\mathrm{h}_{\mathrm{a}}$ diterima. Berarti terdapat pengaruh positif yang signifikan antara variabel $\mathrm{x}$ dan variabel y.Hasil Uji $\mathrm{T}$ menunjukkan $\mathrm{t}_{\text {hitung }}$ lebih besar dari $\mathrm{t}_{\text {tabel, }}, 6,029 \geq 1.985$, artinya Ho ditolak atau Ha diterima. Dan hasil perhitungan diperoleh koefisien determinasi sebesar 0,27,7 artinya nilai korelasi sebesar 27,7 persen variabel independen dapat menjelaskan deviasi dan variabel dependen, sedangkan sisanya 72,3 persen ditentukan oleh variabel lain.

Berdasarkan penelitian yang telah dilakukan akan memberi dampak proses pembelajaran yang lebih baik. Beberapa yang implikasi dalam penelitian ini sebagai bentuk pengembangan proses pembelajaran sebagai berikut:

Pihak sekolah diharapkan dapat memfasilitasi proses pembelajaran yang berbasis komputer. Ketersedian sarana prasarana dalam proses pembelajaran akan lebih memaksimalkan motivasi, minat dan perhatian peserta didik sehingga prestasi dan hasil belajar bisa maksimal.

\section{DAFTAR PUSTAKA}

Ahmadi, Abu. 2009. Psikologi Umum. Jakarta: Rineka Cipta.

Echols, John M. dan Shadily, Hasan. 1996. An English-Indonesia Dorectory.Cet. 23; Jakarta: Gramedia.

Hadis.Abdul, 2006. Psikologi dalam Pendidikan. Bandung: Alfabeta.

Jacob, L.C. Ary Donald and Asghar, Razavewh.Introduction to Research Introduction. 1985. 3th Edition New York: Holt, Renehart and Winston.

Khairani. Makmun. 2013. Psikologi Belajar.Yogyakarta: Aswaja Pressindo.

Kisworo, Marsudi Wahyu. 2016.Revolusi Mengajar: Pembelajaran Aktif, Kreatif, Efektif, Menyenangkan Pakem. Jakarta: Asik Generation. 
Majid, Abdul dan Andayani, Dian, 2004.Pendidikan Agama Islam Berbasis Kompetensi. Bandung: Remaja Rosdakarya.

al Maraghi, Ahmad Musthafa. 1993.Terjemahn Tafsir Al Maraghi, jilid 6, Cetakan ke-2, Semarang PT. Karya Toha Putra.

Mulyasa, E. 2007. Kurikulum Tingkat Satuan Pendidikan.Cet. 3; Bandung: Remaja Rosdakarya.

Mulyasa, E. 2008. Menjadi Guru Profesional, Menciptakan Pembelajaran Kreatif dan Menyenangkan.Cet. 8; Bandung: Remaja Rosdakarya.

al- Nahlawi, Abdurrahman. 1992. Prinsip-prinsip dan Metode Pendidikan Islam, Bandung: CV. Diponegoro.

Nawawi, Hadari. 1995. Metode Penelitian Bidang Sosial.cet.VII; Yogyakarta: Gajah Mada University Press.

Sardiman, A.M. 2011. Interaksi dan Motivasi Belajar Mengajar, Jakarta: Raja Grafindo Persada. 